DOI: 10.22616/REEP.2019.037

\title{
Importance of Dietary Habits for Military Personnel
}

\author{
Liana Plavina ${ }^{1}$ Dr. med.; Sandra Gegere ${ }^{2}$ Bc. sc.sal. \\ Riga Stradins University of Latvia; Latvia \\ liana.plavina@rsu.lv1; sandra.gegere@gmail.com²
}

\begin{abstract}
Nutrition habits of cadets are basement for keeping health and physical preparedness stability, developing a military career. General obligation of each military person is to take care of his welfare and health, to follow to the hygiene standard and keep military readiness and physical fitness. Welfare includes also healthy, balanced and adapted to the physical load nutrition. According the legislation military person get daily financial support-compensation for daily food. There is individual responsibility to choose food that is suitable and available, that favour physical fitness and increase health status. The aim of our study is to indicate the nutrition habits of cadets of National defence academy of Latvia. We have provided a questionnaire about food consumption of cadet's groups in period from 2017 till 2018. The study data were processed by SPSS 22. Results reflect that cadets' general information level and understanding about importance of food consumption need to be improved. It is useful to organise the lectures course about the main principles of healthy nutrition adapted to physical load. The cadets need additional information about balanced diet. The recent research suggests that a significant percentage of cadets do not have adequate nutrition habits to physical activity level. We fixed problems (deficit of water consumption) before the sports activities. Balanced food consumption allows improving physical status and working capacities of cadets and correlating the body mass index (BMI) value to Standard level. The correctly organized nutrition plan helps to support physical fitness and activity of military personnel.
\end{abstract}

Keywords: dietary habits, military personnel, physical fitness, nutritional habits, university education.

\section{Introduction}

Recent data has suggested that there is more interaction between diet and physical training results. The military training included as well physical endurance training as well military skills training. Macronutrients are the energy or protein building blocks and are topical for adaptation to situation with definite physical or mental load (Burke, 2010; Moore et al., 2009). We were interested in data about cadets' nutrition habits. The cadets are receiving financial support (compensation) for daily nourishment. They manage food and fluid intakes by themselves. It is very important that the cadets are correctly organizing their daily feeding plan.

The information about nutritional habits of Latvian inhabitants was collected by the health monitoring projects (Latvia Health Behavior..., 2014; Latvijas iedzivotaju veselibu..., 2017). The positive trend regarding Latvian inhabitants' sugar using was observed - it decreased to $20 \%$ of respondents compared to $18.5 \%$ of respondents in 2014 . The data of Latvian inhabitant's questionnaire showed, that the vegetable consumption increased from $25.3 \%$ (in 2014) till $27.1 \%$ (in 2016). The data of monitoring showed the fat food consumption also diminished $22.7 \%$ of respondents in 2016 (comparing to $19.6 \%$ of respondents in 2014). The monitoring data showed the $42.8 \%$ of respondents changed their nutritional habits due to their health problems in 2014, but in $201626.6 \%$ of respondents had to change their dietary habits. The health monitoring reflected that the part of Latvian inhabitants didn't pay attention to their dietary. The cadets' nutrition habits were essential to maintain and support physical fitness and working capacities, which are very important for general military readiness and preparedness. The cadets' daily physical activities and training plans directed to the increase of fitness and force capacities.

The education level and intelligence, knowledges about nutrition and its importance for keeping health and working capacity correlated to education level (Kullen et al., 2016; (Jezewska-Zychowicz, 2018).

The aim of study was to analyse the nutritional habits of military personnel - cadets, their understanding and knowledge level concerning the nutritional importance for support of physical working capacities.

\section{Methodology}

We provided the questionnaire to cadets' groups of National defence academy of Latvia. The study included 143 respondents of both genders (130 male and 13 female). They had military service 
experience duration from one year to nine years. Questionnaire was adapted to study group and was forming on the grounds of Sports Nutrition Knowledge Questionnaire (Kummer, 2016) and Nutrition Knowledge Questionnaire (Clemo, 2014). Our questionnaire included 23 questions that allowed collecting information about nutrition habits, fluid intake knowledge concerning nourishment and fluid intake importance for keeping working capacity during hard physical load condition.

Riga Stradins University Etic committee accepted the study. Data was processed by using MS Office program Excel and statistic program SPSS 22.

\section{Results and Discussion}

The nutrition plays the key role in skeletal muscle adaptation response to physical exercise training that modulates muscle reconstruction. Dietary protein intake stimulates skeletal muscle protein synthesis, inhibits muscle proteins breakdown that lead' to a greater muscle adaptation to exercise (Cermak et al., 2012, Phillips, van Loon, 2011). The daily protein recommendation for protein intake for health adults is $0.8 \mathrm{~g} / \mathrm{kg} / \mathrm{day}$ (Phillips, van Loon, 2011; Slater, Phillips, 2011). There is no exact window of time for protein consumption, the athletes should maintain protein balance throughout the day (Hartman et al., 2007; Moore et al., 2012; Tang et al., 2009) The essential part of physical performance is the individual and collective skills, weather conditions, surrounding characteristics, but nutritional effect is important also. The analyses of questionnaire data showed the nutritional habits of cadets - next officers and allowed to find out the respondents' knowledge level about importance of balanced nutrition and proper fluid intake for military performance.

The assessment of respondents' answers concerning meal times per day: 58,5\% of respondents had three till four meal times per day, but $17.5 \%$ of respondents considered that for keeping physical endurance and fitness five till six meal times daily are necessary (Figure 1).

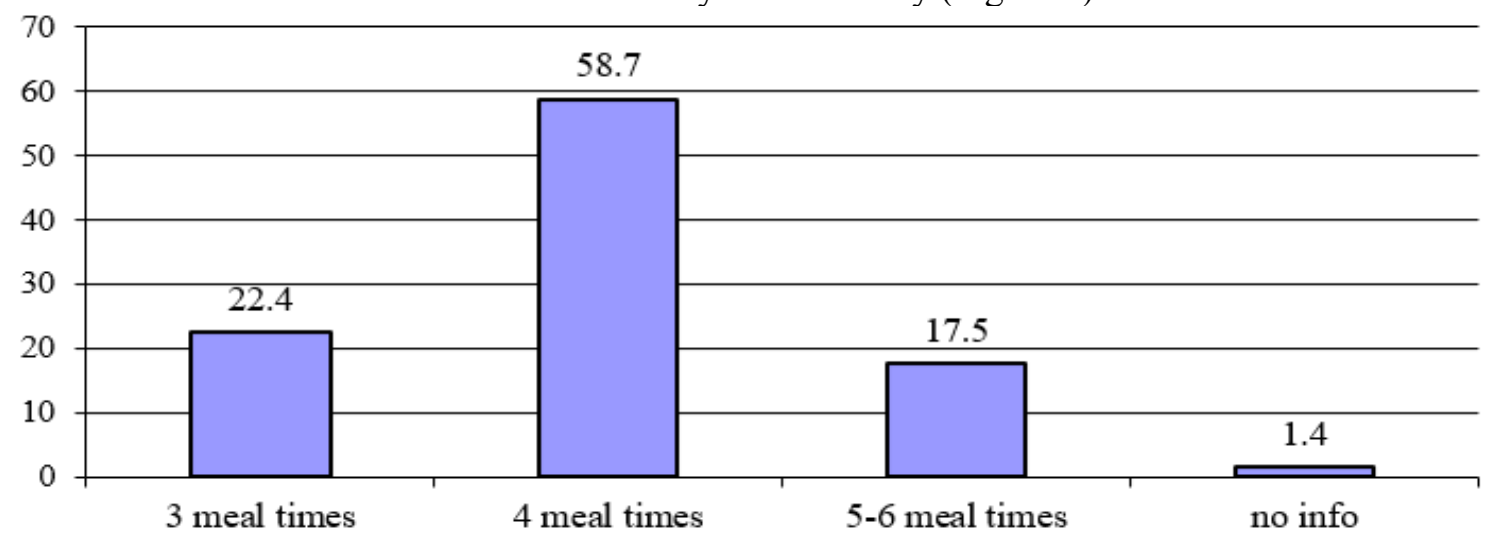

Figure 1. Distribution of respondents by meal times per day (\%).

The regular food intake improves the physical training results; the most important meal time is the breakfast (Cermak et al., 2012).

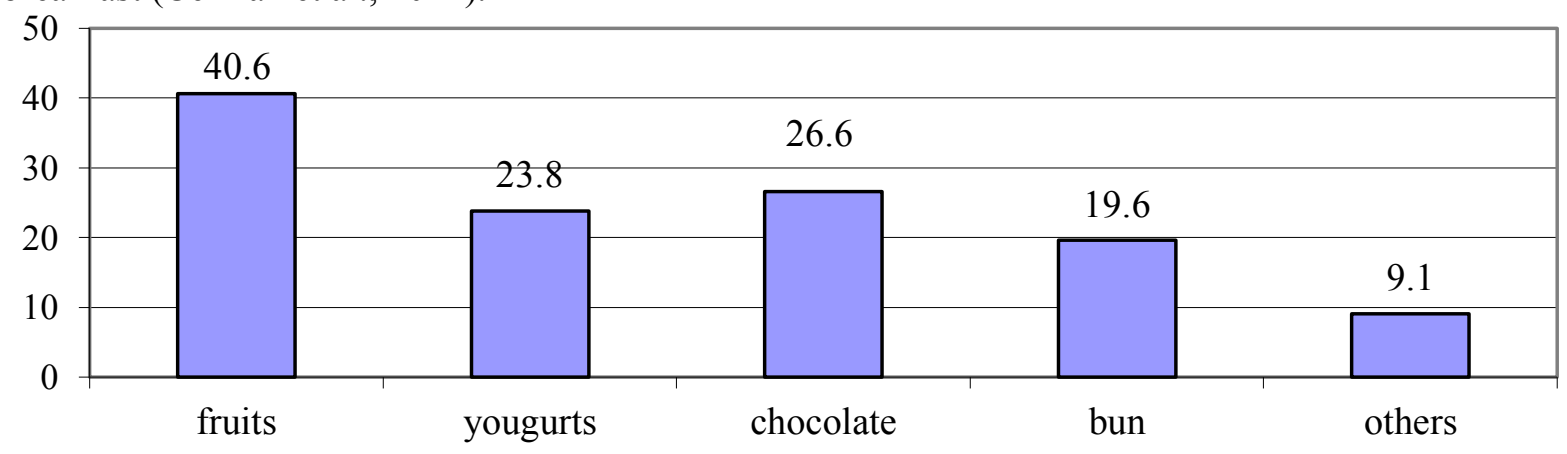

Figure 2. Distribution of respondents by various snack intakes (\%).

The first meal time (breakfast) should contain about 30-40\% of calories rate from daily amount. Todays the breakfast's importance is decreased, and cadets preferred the lunch (about $79 \%$ ), which is the largest meal and delivers the largest calories intake for our respondents' groups. The cadets had the snacks 
between the main meals. The respondents choose various carbohydrates rich with minimal fibres, fat and protein food: fruit (40.6\%), yogurts $(23.8 \%)$, chocolates $(26.6 \%)$, bun $(19.6 \%)$ etc. (Figure 2$)$.

The various products contain proteins: eggs $(32 \%)$ milk products $(35.4 \%)$, legume $(6.1 \%)$ meat and fish $(58.5 \%)$. The various studies inform about improvement in protein balance and protein synthesis rates in case of ingestion of whey proteins (Tipton et al., 2004), casein protein (Tipton et al., 2004), soy protein (Wilkinson et al., 2007), casein protein hydrolysate (Koopman et al., 2004; Koopman et al., 2006; Koopman et al., 2009), whole milk and /or fat-free milk (Eliot et al., 2006, Wilkinson et al., 2007). The milk products are well available to use in Latvian regions. The milk products are resources for proteins (a blend of whey and casein) and calcium. $58 \%$ of cadet's use milk products daily, $22.4 \%$ of respondents include milk products in diet three time per week, but $2.8 \%$ do not use milk products at all (Figure 3 ).

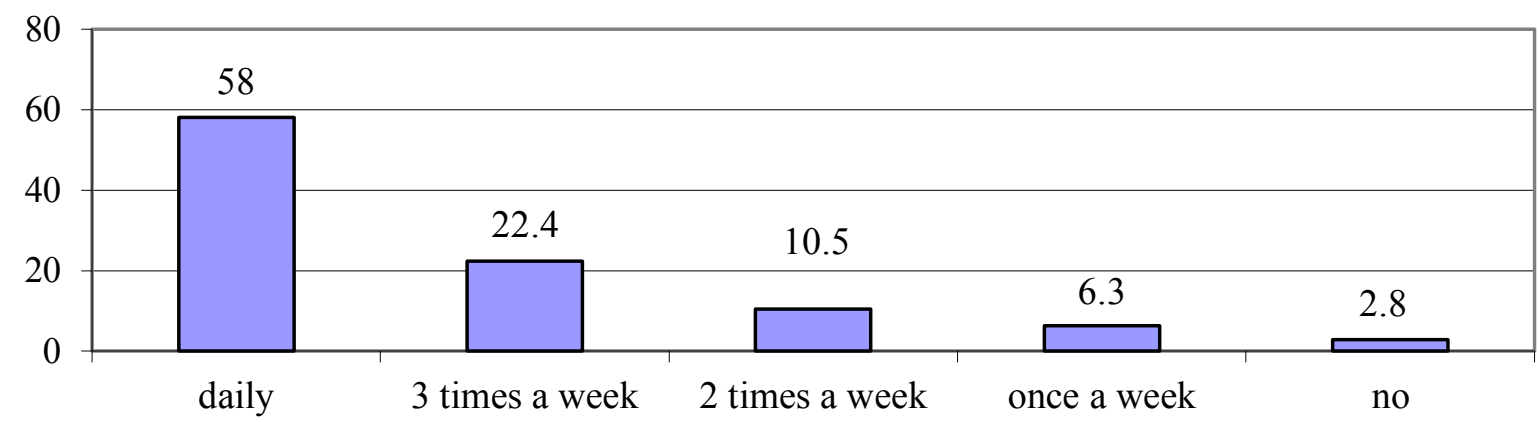

Figure 3. Distribution of respondents in groups by various milk products intakes (\%).

The regular intake the recovery proteins can help to improve physical readiness and training results. Analysis of post exercise protein consumption during resistance training increased fat free mass (Cermak et al., 2012), cross-sectional area of muscle fibres (slow and fast twitch). According to our questionnaire results the meat was the main resource of proteins for cadets. $73.4 \%$ of respondents included the meat in the diet daily (Figure 4). About $18.9 \%$ of respondents included the meat into the meal three times per week. The respondents' choose different kind of meat. The $81.5 \%$ of respondents preferred chicken, $23.8 \%$ of respondents used pork and the $16.9 \%$ of respondents had beef.

The primary protein role is to provide the building resources to create individual protein structures in the body. The consumption of complete proteins supports muscular tissue recovering processes. The physical exercise training causes the process of breaking down muscle structures and building new structures. The dietary protein resources should contain all of essential amino acids. The amino acid profile is important for choosing dietary proteins. Meat and fish are complete, containing all essential amino acids (Slater, Phillips, 2011).

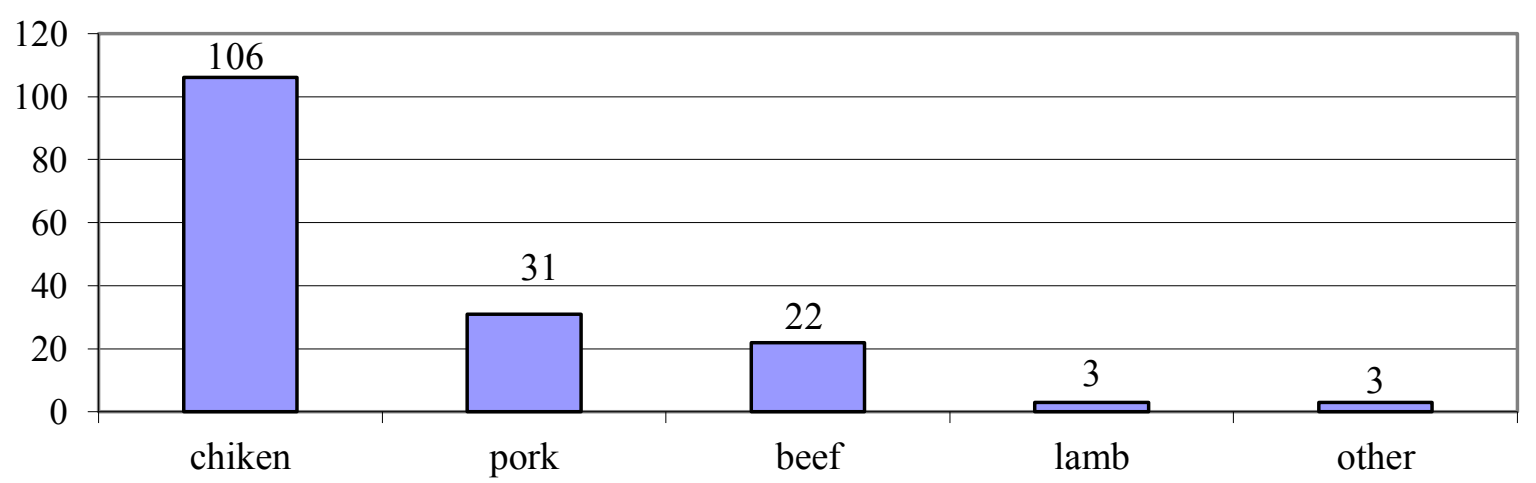

Figure 4. Distribution of respondents by various meat intakes (number of respondents).

The fish is a product that contains very important component omega- 3 fat acids. The fish should be included in the dietary for everyone, especially for persons with physical load, but results of questionnaire of study group respondents indicated that about $50.4 \%$ of them didn 't include fish in daily meal at all, $39.2 \%$ of respondents uses the fish once per week and only some had fish food three times per week (Figure 5). 


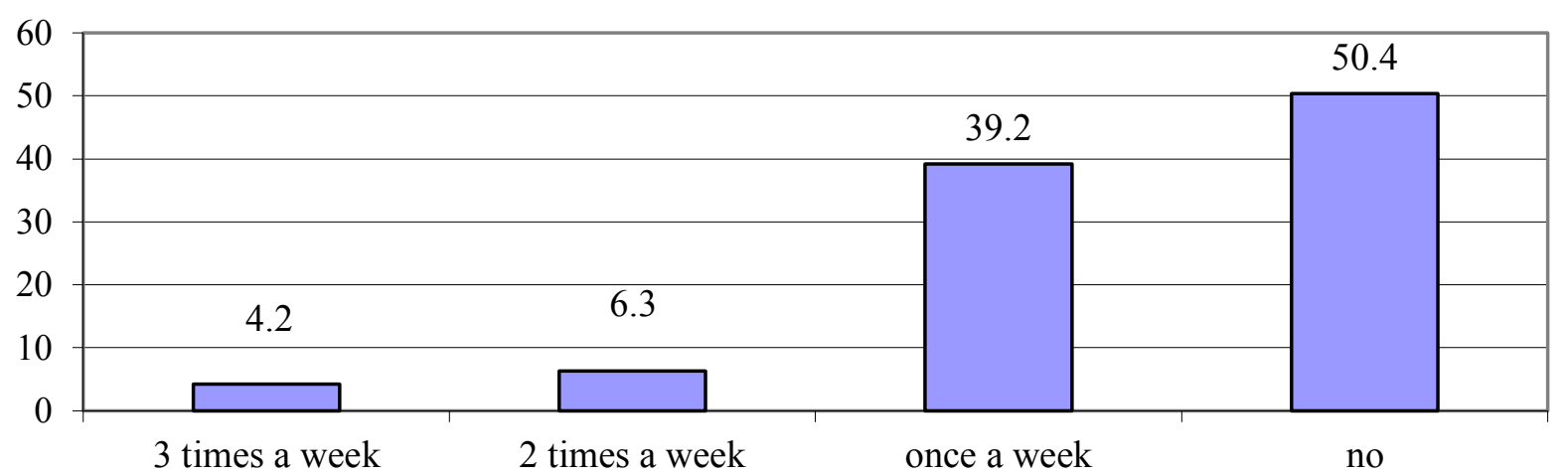

Figure 5. Distribution of respondents by fish products intakes (\%).

Carbohydrates play fundamental role in energy providing for endurance physical performance, they are crucial also in post exercise period when the glycogen depleted, when muscular tissue characterised with process of breaking down muscle structures and building new structures (Burke et al., 2011). The person involved in endurance training focuses on carbohydrate ingestion that accelerates post-exercise recovery. Co-ingestion of small amounts of proteins can accelerate muscle glycogen repletion when less then optimum amounts of carbohydrate are ingested during first few hours of post exercise recovery (Beelen et al., 2011, 2012). It is important to combine carbohydrates intakes for energy demand and fluid for hydration.

Fruits and vegetables are an important part of a diet. They are an important source of fibres, vitamins, minerals and antioxidants. About $41.9 \%$ of cadets daily add vegetables in diet. $32.2 \%$ of respondents include vegetables in diet three times per week, and $18.2 \%$ of respondents consume vegetables two times per week (Figure 6).

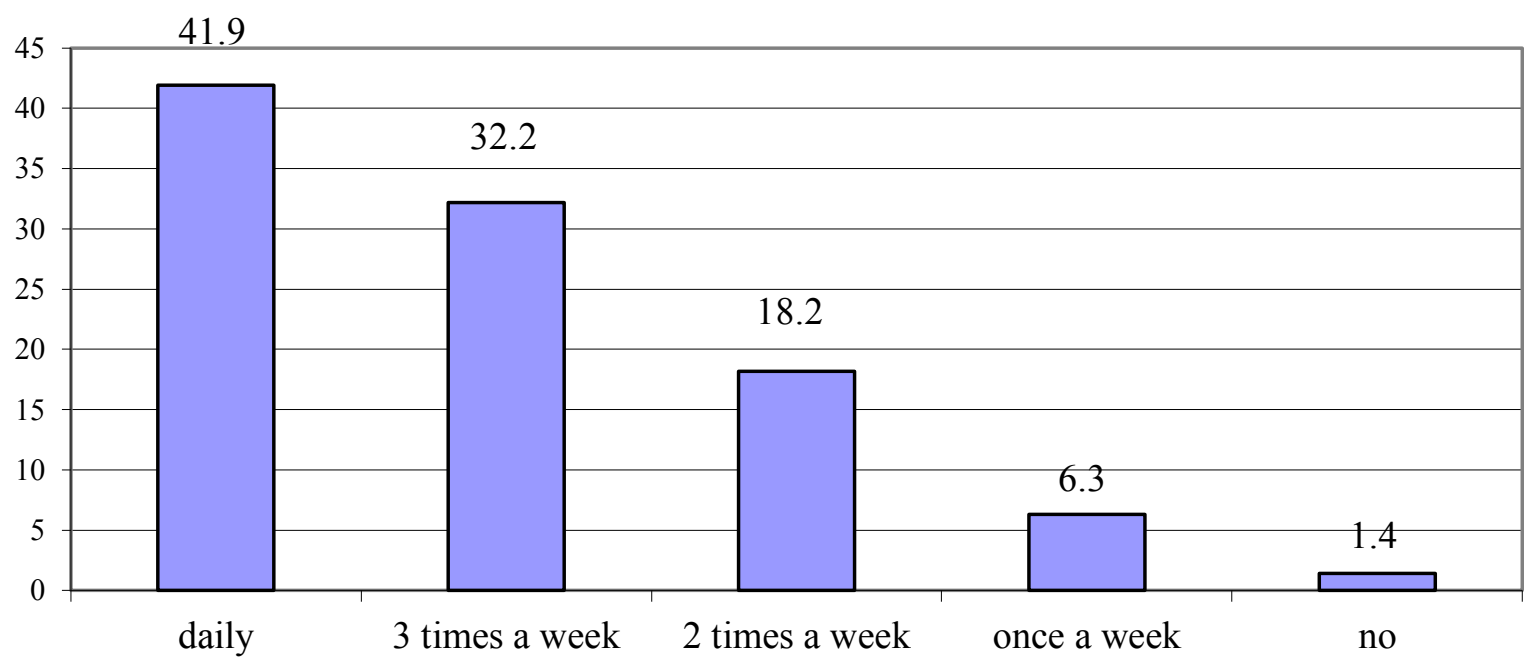

Figure 6. Distribution of respondents by vegetable products intakes (\%).

In Latvian population's dietary habits, the potatoes are more popular than legumes. Three times per week potatoes consumed by $33.6 \%$, while legumes only $13.9 \%$. Vitamins and minerals are essential components of daily food, they play an important role in energy metabolism. Fruits are important and well-used products for vitamins and minerals. They were included in daily use for $30.8 \%$ of respondents. Three times in a week the fruits were preferred by $32.2 \%$ of cadets and $25.9 \%$ of respondents used fruits twice a week (Figure 7). 


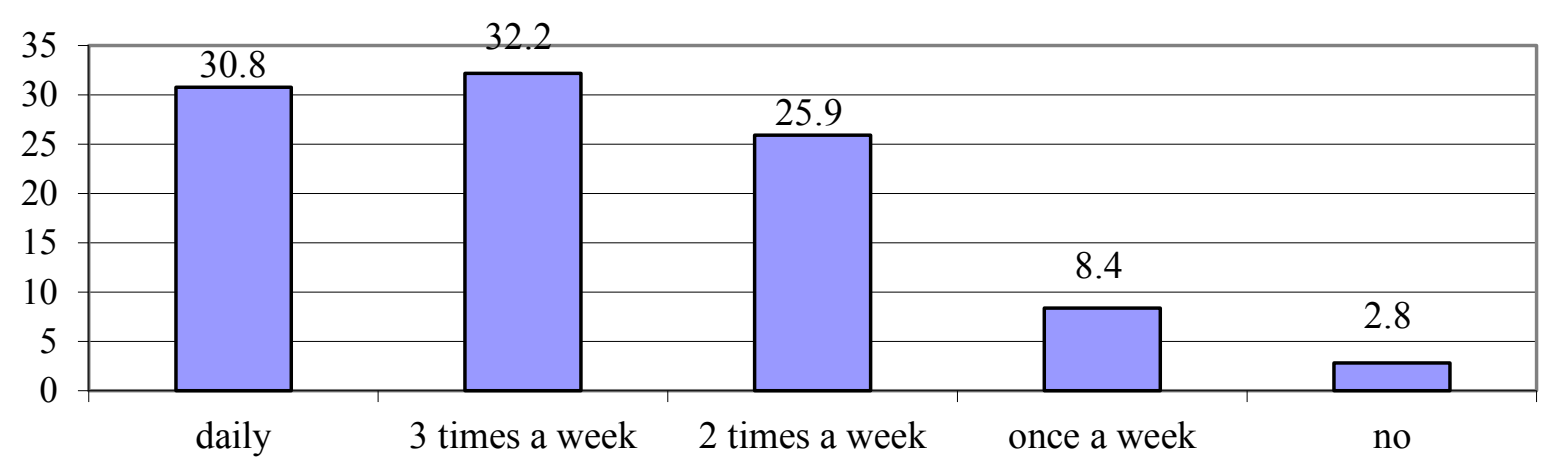

Figure 7. Distribution of respondents by fruit intakes (\%).

We analysed fat reach product choose. $51.3 \%$ of respondents preferred fat-rich meat, $42.3 \%$ of respondents preferred soured cream and mayonnaise. In general, $83.6 \%$ of the study group members favour predominating saturated fats (Figure 8).

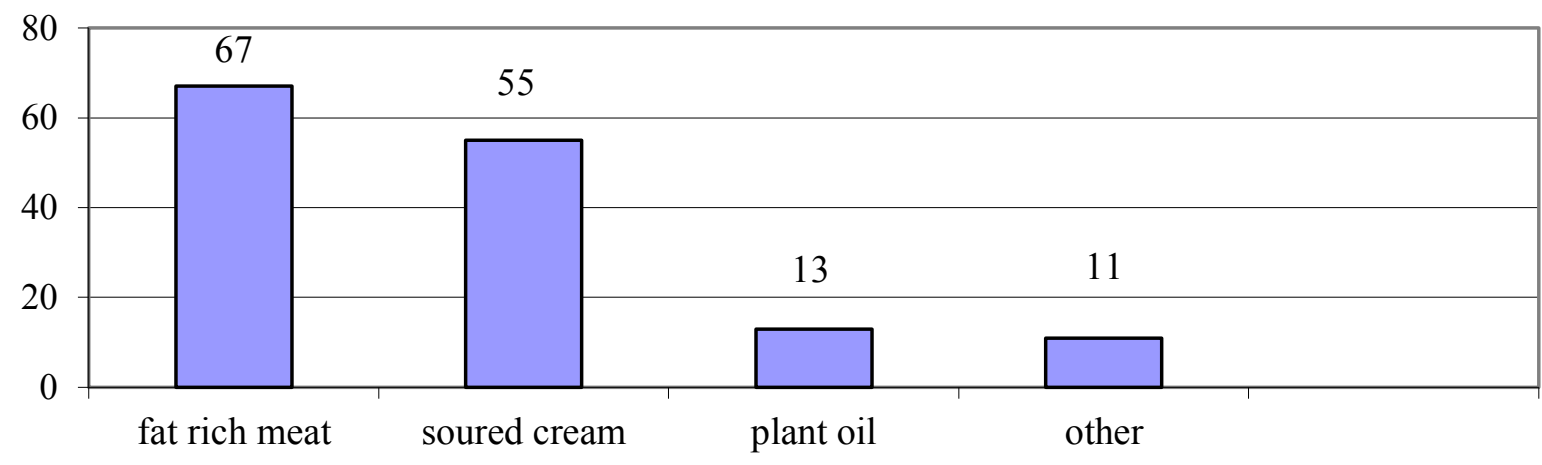

Figure 8. Distribution of respondents by various fat reach product intake (number of respondents).

\section{Conclusions}

The cadets' dietary habits showed by using of wide variety of food what covered balanced energy needs. The eaten food included rich amount of proteins (meat) and fat. On a daily basis, cadets absorb all nutritional groups, putting a lot of emphasis on protein, receiving it through meat and dairy products, paying less attention to fish and legumes. It is based on the desire to maintain their physical capacity. The cadets' diet quality should be balance by adding fish products, vegetables, and fruits intakes. Vegetables and fruits provide all necessary amounts of vitamins and minerals. The cadets follow to three till four meals per day plan that provide all necessary energy. Between meals, snacks are included, and water is used to quench thirst but in one-third of the cases the consumed amount less than what is needed. The fluid intake should be improved by drinking fluid throughout the day (water, juices, and tea) and by body weight control after the physical exercises. In order to maintain cadets' physical working capacity and reduce the likelihood of health problems, cadets must be educated on the creation of a balanced diet and the right drinking regimen, as well as on the safety of the use of nutritional supplements, which matches with the desire and interest of cadets to expand their knowledge of adequate nutrition regimens. The cadets are interested to improve their diet by its balancing according physical activities load and maintaining a healthy weight.

\section{Bibliography}

1. Beelen M., Kranenburg J.V., Senden J.M., Kuipers H., van Loon L.J. (2012). Impact of caffeine and protein on post-exercise muscle glycogen synthesis. Medicine \& Science in Sports \& Exercise, 44(4), 692-700.

2. Beelen M., Zorenc A., Pennings B., Senden J. M., Kuipers H., van Loon L. J. (2011). Impact of protein congestions on muscle protein synthesis during continuous endurance type exercise. American Journal Physiology Endocrinology and Metabolism, 300(6), 945-954.

3. Burke L.M. (2010). Fuelling strategies to optimize performance: training high or training low? Scandinavian Journal of Medicine \& Science in Sports, 20 (2), 48-58.

4. Burke L.M., Hawley J.A., Wong S.H.S., Jeukendrup A.E. (2011). Carbohydrates for training and competition. Journal of Sports Sciences, 29 (1), 17-27. 
5. Cermak N.M., Res P.T., de Groot L.C., Saris W.H., van Loon L.J. (2012). Protein supplementation in augments the adaptive response of skeletal muscle to resistance exercise training: a meta-analysis. American Journal of Clinical Nutrition, 96(6), 1454-1464.

6. Clemo M.F. (2014). The relationship between nutrition knowledge and performance measures in British collegiate American football athletes. Retrieved from https:/uhra.herts.ac.uk/bitstream/handle/2299/13868/08174103\%20-\%20Clemo\%20Matthew\%20-\% 20MSc\%20by\%20Research\%20final\%20submission.pdf?sequence=1\&isAllowed=y

7. Eliot T.A.A., Cree M.C., Sanford A.P., Wolfe R.R., Tipton K.D. (2006). Milk ingestion stimulates net muscle protein synthesis following resistance exercise. Medicine \& Science in Sports \& Exercise, 38(4), 667-674.

8. Hartman J.W., Tang J.E., Wilkinson S.B., Tarnopolsky M.A., Lawrence R.L., Fullerton A.V., Phillips S. M. (2007). Consumption of fat-free fluid milk after resistance exercise promotes greater lean mass accretion than does consumption of soy or carbohydrates in young, novice, male weightlifters. American Journal of Clinical Nutrition, 86(2), 373-381.

9. Jezewska-Zychowicz M. (2018). Cooking Methods, Social Relations and Situations Related to Food as a Part of Nutrition Education within Family. In V. Dislere (Ed.), The Proceedings of the International Scientific Conference Rural Environment. Education. Personality. (REEP), 11, 261-268. Retrieved from http://lufb.llu.lv/conference/REEP/2018/Latvia_REEP_2018_proceedings_ISSN2255808X-261-268.pdf

10. Koopman R., Crombach N., Gijsen A.P., Walrand S., Fauqaunt J., Kies A.K., Lemosquet S., Saris W.H., Boirie Y., van Loon L.J. (2009). Ingestion of protein hydrolysate is accompanied by an accelerated in vivo digestion and absorption rate when compared with its intact protein. American Journal of Clinical Nutrition, 90(1), 106-115.

11. Koopman R., Pannemans D.L., Jeukendrup A.E., Gijsen A.P., Senden J.M., Halliday D., Saris W.H., van Loon L.J., Wagenmakers A.J. (2004). Combined ingestion of protein and carbohydrate improves protein balance during endurance exercise. American Journal of Physiology Endocrinology and Metabolism, 287(4), E712-E720.

12. Koopman R., Wagenmakers A.J., Manders R.J., Zorenc A.H., Senden J.M., Gorselink M., Keizer H.A., van Loon L.J. (2006). Combined ingestion of protein and leucine stimulates muscle protein synthesis rates to the same extent in young and elderly lean men. American Journal of Clinical Nutrition, 84(3), 623-632.

13. Kullen C.J., Frrugia J.L., Pravn T., O`Connor H.T. (2016). Relationship between general nutrition knowledge and diet quality in Australian military personnel. British Journal of Nutrition, 115(8), 1489-1497.

14. Kummer A. (2016). Sports Nutrition for the Adolescent Athlete: The WAVE Pilot Study. Oregon, USA: Oregon State University.

15. Latvia Health Behavior among the Adult Population 2014. (2014). Retrieved from: http://ghdx.healthdata.org/record/latvia-health-behavior-among-adult-population-2014

16. Latvijas iedzivotaju veselibu ietekmejoso paradumu petijums, 2016 (Research on habits affecting the health of the Latvian population 2016). (2017). Riga: Slimibu profilakses un kontroles centrs. Retrieved from https://spkc.gov.lv/upload/Petijumi\%20un\%20zinojumi/FINBALT/finbalt_2016_2.pdf (in Latvian)

17. Moore D.R., Areta J., Coffey V.G., Stellingwerff T., Phillips S.M., Burke L.M., Cleroux M., Godin J.P., Hawley J.A. (2012). Daytime pattern of post-exercise protein intake affects whole-body protein turnover in resistance-trained males. Nutrition and Metabolism, 9(1), 91.

18. Moore D.R., Robinson M.J., Tang J.E., Glover E.I., Wilkinson S.B., Prior T., Tarnopolsky M.A., Phillips S.M. (2009). Ingested protein dose response of muscle and albumin protein synthesis after resistance exercise in young men. American Journal of Clinical Nutrition, 89(1), 161-168.

19. Phillips S.M., van Loon L. (2011). Dietary protein for athletes: from requirement to optimum adaptation. Journal of Sports Sciences, 29(1), 29-38.

20. Slater G., Phillips S.M. (2011). Nutrition guidelines for strength sports: sprinting, weightlifting, throwing events and bodybuilding. Journal of Sports Sciences, 29(1), 67-77.

21. Tang J. E., Moore D.R., Kujbida G.W., Tarnopolsky M.A., Phillips S.M. (2009). Ingestion of whey hydrolysate, casein, or soy protein isolate: effects on mixed muscle protein synthesis at rest and following resistance exercise in young men. Journal of Applied Physiology, 107(3), 987-992.

22. Tipton K.D., Eliot T.A., Cree M.G., Wolf S.E., Sanford A.P., Wolffe R.R. (2004). Ingestion of casein and whey proteins result in muscle anabolism after resistant exercises. Medicine \& Science in Sports \& Exercise, 36(12), 2073-2081.

23. Wilkinson S.B., Tarnopolsky M.A., Macdonald J.R., Armstrong D., Phillips S.M. (2007). Consumption of fluid skim milk promotes accretion after resistance exercise than does consumption of an isonitrogenous and isoenergic soy - protein beverage. American Journal of Clinical Nutrition, 85(4), 1031-1040. 